\title{
Catastrophes versus events in the geologic past: how does the scale matter?
}

GUTAK, J. M. ${ }^{1}$ and RUBAN, D. A. ${ }^{2,3 *}$

(1) Department of Physical Geography and Geology, Kuzbass State Pedagogical Academy, Kuznetsov Street 6, Novokuznetsk, Kemerovo Region, 654041, Russian Federation; fgg@nvkz.ru, GutakJaroslav@ yandex.ru

(2) Division of Mineralogy and Petrography, Geology and Geography Faculty, Southern Federal University, Zorge Street 40, Rostov-na-Donu, 344090, Russian Federation;

(3) contact address: P.O. Box 7333, Rostov-na-Donu, 344056, Russian Federation; ruban-d@mail.ru, ruban-d@rambler.ru

*corresponding author

https://doi.org/10.17979/cadlaxe.2013.37.0.3589

\begin{abstract}
Catastrophes were common in the geologic past, but their distinction from other events is necessary. Besides magnitude (strength), scales of events are important in a solution of this task. Several examples, which involve Late Paleozoic and Quaternary megafloods, Hadean and Phanerozoic extraterrestrial impacts, and Phanerozoic mass extinctions, ensure that scaling by spatial extent and diversity of consequences facilitates tracing the boundary between catastrophes and "ordinary" events. This boundary, however, is dynamic and its position depends on our subjective needs. Considerations of the geologic past should not mix catastrophes of different scales. The event analysis helps to avoid such a pitfall, and, therefore, it should be preferred to neocatastrophism in modern geoscience.
\end{abstract}

Key words: Catastrophe; event; megaflood; extraterrestrial impact; mass extinction. 


\section{INTRODUCTION}

The Hawaiian creation chant entitled Kumulipo gives a spectacular example of how ancient Polynesians perceived a mix of gradual and sudden events in the development of nature (Beekwith, 1981). Surprisingly, modern geoscientists are faced with the same challenge, namely a clear distinction between catastrophes and other ("ordinary") events. Much has been said about past geologic catastrophes and the rise of neocatastrophism (e.g., DURY, 1980; BERGGREN \& VAN COUVERING, 1984; KARROW, 1989; HICKEY, 1992; SCHÖNLAUB, 1996; HALLAM, 2005; BABIN, 2007; MARRINER et al., 2010). BABIN (2007) has demonstrated recently that event analysis is a desired perspective for modern geoscience. Some classifications of geologic events exist (e.g., RUBAN, 2006), but an appropriate distinction of catastrophes from other events is yet to be achieved. This problem appears to be highly complex, and it requires a multi-dimensional solution.

An objective of the present essay is consideration of some catastrophes discussed in modern geoscience literature in order to demonstrate that their scale was not less important than their magnitude (their distinction is explained below). This can apparently help to create a basis for further distinction of catastrophes from "ordinary" events in the geologic past.

\section{BRIEF THEORETICAL OUTLINE}

The geologic event is nothing more than an occurring (or already occurred) change (RUBAN, 2006). Although modern geoscience often focuses on extraordinary events (e.g., BOGGS, 2006; REY \& GALEOTTI, 2008), which are, in particular, meaningful for stratigraphical correlation purposes, these constitute only a small part of all events that occurred in the geologic past and were either preserved or not in the available geologic record. Catastrophes are, undoubtedly, events, but only a few events are catastrophes. So, how are the latter to be specified? Avoiding an in-depth analysis of the large amount of relevant literature (e.g., MILNE, 2000; POSNER，2004; BOSTROM \& ĆIRKOVIĆ, 2008), it is simple to state that catastrophes are distinguished as a large-scale process with dramatic consequences. Catastrophes are often (but likely not-necessarily) sudden, selfaccelerating, and highly-complex events.

The main characteristic of a catastrophe is its magnitude, i.e., strength. E.g., 95\% of life went extinct at a time of the Permian/Triassic mass extinction (ERWIN, 2006). This suggests an outstanding magnitude. Global warming by $60 \mathrm{C}$ is forecasted to happen during the next decades according to one of the proposed scenarios (HOUGHTON, 2009). This also indicates a magnitude of this potential catastrophe. Taking into account magnitudes of geologic events, one can rank them within the same class and with the same units. E.g., the percentage of species went extinct can help to rank biotic crises. A comparison of events belonging to different classes is a more difficult task (because of different units), which will be possible only on the basis of certain subjective judgements. But if even this is possible, it is definitely not enough to make a distinction from "ordinary" events. The geologic environment is very complex. It has physical dimensions (area and depth), complexity (various geologic bodies and processes), and dynamics (duration, abruptness, and frequency). Thus, one needs to measure the scale of past events, and, consequently, 
to consider their spatial extent, diversity of consequences, and temporal expression.

\section{EXAMPLES}

Three particular subjects reflected in modern geoscience literature are mentioned in this paper in order to illustrate the scaling of catastrophes in the geologic past. These include megafloods, mass extinctions, and extraterrestrial impacts. In all cases, representative examples are considered. They are taken from different time slices of geologic time (Fig. 1).

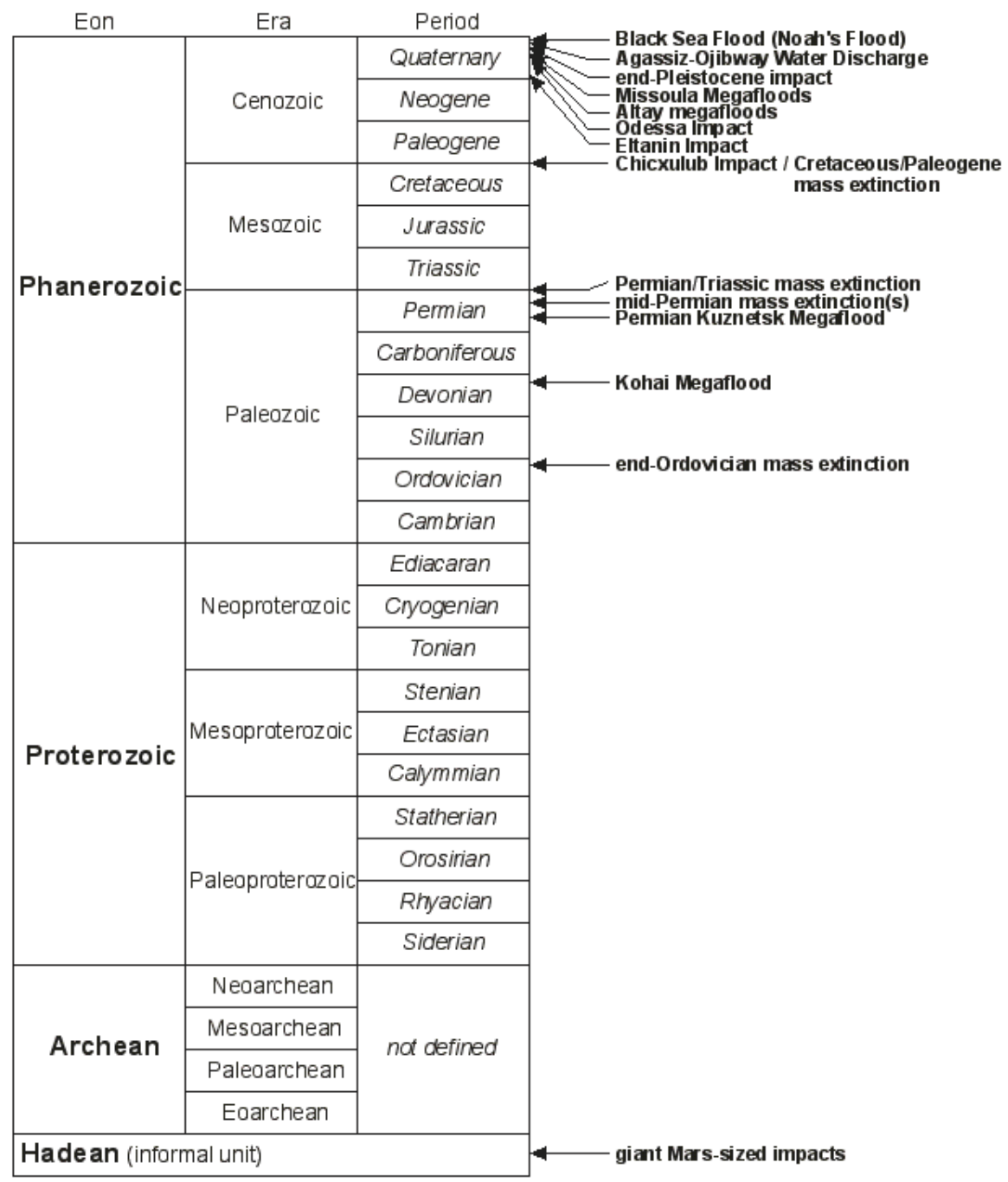

Fig. 1. Catastrophic events considered in the present essay. The geologic time scale is after OGG et al. (2008). 


\section{Megafloods: scaling by spatial extent}

Several megafloods are known from geologic history. One of them is the so-called Missoula Floods. During the Pleistocene, Lake Missoula occupied a large territory in the northwestern part of the USA (chiefly Washington and Oregon). Periodic ruptures of the ice dam, established by a tongue of the Cordilleran Ice Sheet, produced major floods (see reviews in BRETZ, 1969; ANDERSON \& ANDERSON, 2010; see also Appendix) also termed jökulhlaups (VAN LOON, 2009; ANDERSON \& ANDERSON, 2010). It is reasonable to note that the differences between such megafloods from glacial lake outburst floods are rather artificial (Bennett \& Glasser, 2009). Now, up to 90 floods linked with the Missoula lake are reported from the time interval of $18-15 \mathrm{ka}$, although there is evidence that similar floods occurred through the entire Pleistocene (O'CONNOR \& BAKER, 1992; BENITO \& O'CONNOR, 2003; CLAGUE et al., 2003 PLUHAR et al., 2006; ANDERSON \& ANDERSON, 2010; MEDLEY \& BURNS, 2010). MEDLEY \& BURNS (2010) traced the history of these floods back to $780 \mathrm{ka}$ at least. Lake Missoula was up to $200 \mathrm{~m}$ deep, and its volume was about $2700 \mathrm{~km}^{3}$, which allowed peak discharges of $13000000 \mathrm{~m}^{3} / \mathrm{s}$ and the duration of one flood during about a week (ANDERSON \& ANDERSON, 2010). Each event devastated a very large area and re-shaped the landscape now termed channeled scabland. The Missoula Floods, however, were catastrophic for only the northwestern part of the USA (and, probably, neighbouring parts of Canada). They may be, probably, recognized as such on a continental, but not global scale.

The other famous megaflood, sometimes called Noah's Flood, occurred in the
Black Sea Region. It is assumed that the Black Sea with its relatively low level $(150 \mathrm{~m}$ below present) was isolated from the Marmara Sea and the Mediterranean at the beginning of the Holocene; sudden opening of the Bosporus Gateway at 8.5-7 ka allowed a rapid water discharge with a consequent drowning of the Black Sea shelves and quick retreat of the shoreline (RYAN \& PITMAN, 1999; RYAN et al., 2003; Yanko-Hombach et al., 2007; Lericolais et al., 2009; ANDERSON \& ANDERSON, 2010). In the worst case, the sea-level rose by $\sim 0.5 \mathrm{~m} /$ day with horizontal shifts of the shoreline by $\sim 1 \mathrm{~km} /$ day (ANDERSON \& ANDERSON, 2010). Despite strong geological argumentation, this scenario faces some criticism (Görür et al., 2001; Aksu et al., 2002; YANKOHOMBACH et al., 2007). If the Black Sea Flood was true, it was a catastrophe with consequences for earlier human cultures developed along the coasts of the preexisting lake (RYAN \& PITMAN, 1999). Indeed, the whole ecosystem of the Black Sea and neighbouring territories changed dramatically. There might have been some consequences for the Marmara Sea (and, less probably, for the Mediterranean Sea) as well as for the water exchange between the Black Sea and the Caspian Sea. However, it is unlikely that this dramatic event was a catastrophe on the global scale.

Some megafloods are reported from Southern Siberia. In the Middle Frasnian (Late Devonian), there was a voluminous discharge of fresh water from the large Kohai Lake that took place in the Minusa Depression to the marine basin, which embraced the Kuznetsk Basin (GUTAK \& ANTONOVA, 2006a,b). This became possible after breakup of a natural barrier somewhere in the Kuznetsk Alatau. Together 
with water, a lot of clastic sediment was delivered. The relevant red-coloured deposits are preserved as a clinoform with structures typical for diluvial (i.e., formed as a result of flood) beds. A sudden megaflood occurred in the same Kuznetsk Basin in the Permian (GUTAK, 2008). The thickness of the relevant diluvial deposits is up to $17 \mathrm{~m}$. They bear large cordaite stems (Photo 1). This megaflood event was also linked with water discharge from a lake in the Minusa Depression. It appears that rapid burial of organic matter with voluminous clastic material delivered by megafloods in the Kuznetsk Basin facilitated formation of coals (GUTAK, 2008). Megafloods from glacial-dammed lakes are also reported from the Late Pleistocene of the Altay (BUTVILOVKIJ, 1993; Grosvald, 1999; RUDOY, 2002; GUTAK et al., 2008). The largest Tchuja Lake was up to $140 \times 70$ $\mathrm{km}$ in size with depth up to $300 \mathrm{~m}$ (GUTAK et al., 2008). Destruction of ice dams resulted in cataclysmic outflow of lake waters, which occurred within some days. Peak water discharges in the Altay reached $18000000 \mathrm{~m}^{3} / \mathrm{s}$ (RUDOY, 2002). Specific landforms like giant ripples (Photo 2) and flood terraces (Photo 3) were created by these floods. The whole landscape became a scabland (RUDOY, 2002) similar to that described in North America (see above). Interestingly, megafloods took place in the Altay until the mid-Holocene (RUDOY, 2002; GUTAK et al., 2008), which permits one to hypothesize that not only the landscape, but also prehistoric human societies were affected by these events. In all three cases, water discharges were, undoubtedly, catastrophic and perturbed the local palaeoenvironments and sedimentation regime. However, these catastrophes are recognizable only on the regional scale limited by the territory of Southern Siberia.

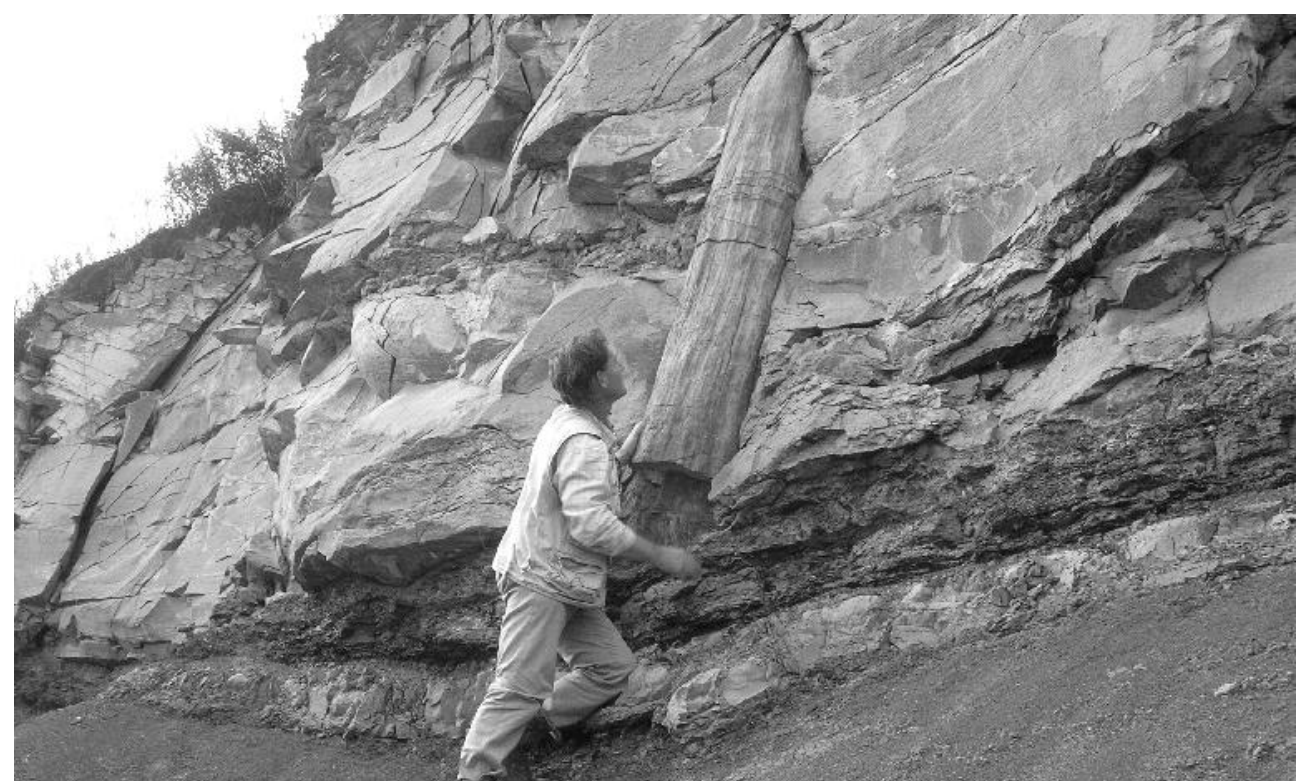

Photo. 1. Permian diluvial bed with a cordaite stem ( $7 \mathrm{~m}$ in length) in the Kuznetsk Basin. I. DULIĆ stays for scale. Photo by JA.M.G. 


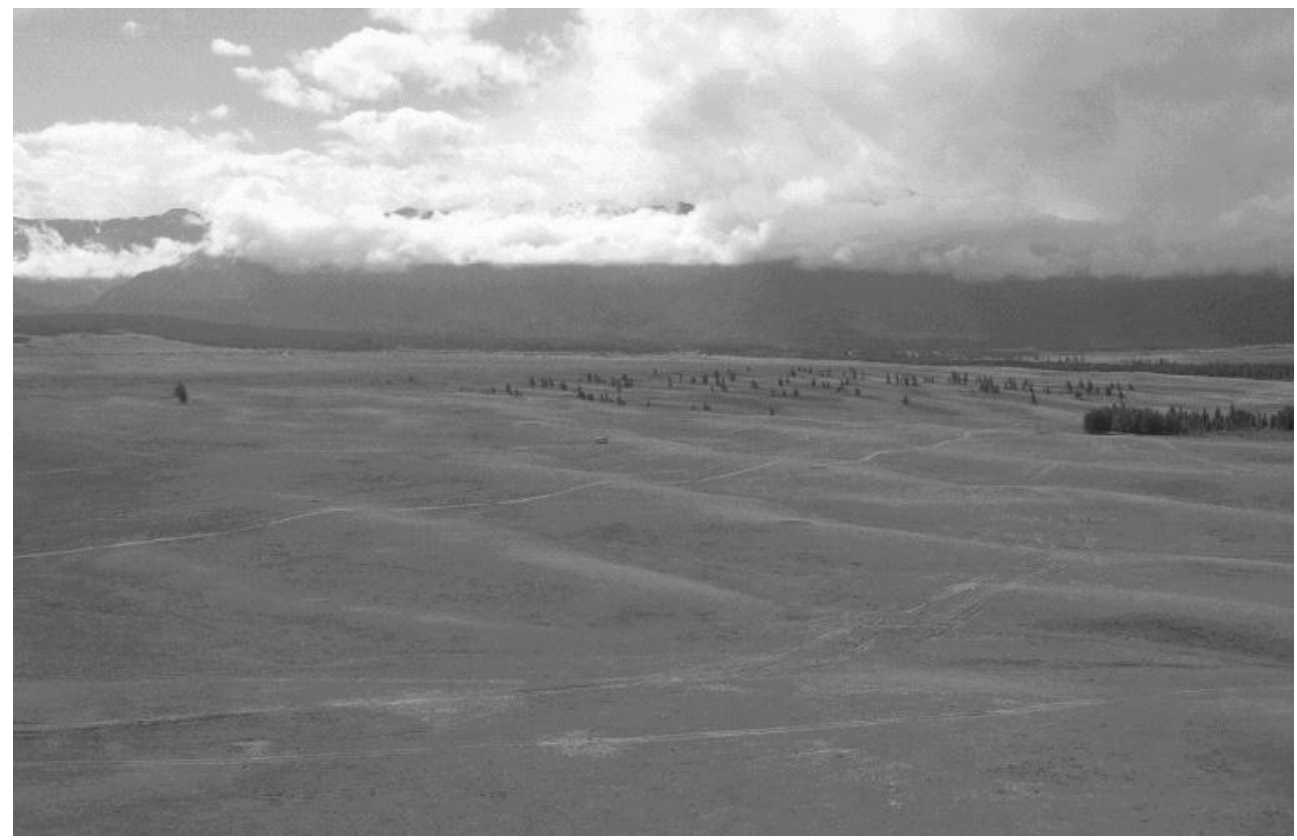

Photo 2. Giant ripples of ancient megaflood in the Altay. The height of ripples is up to $20 \mathrm{~m}$. Photo by JA.M.G

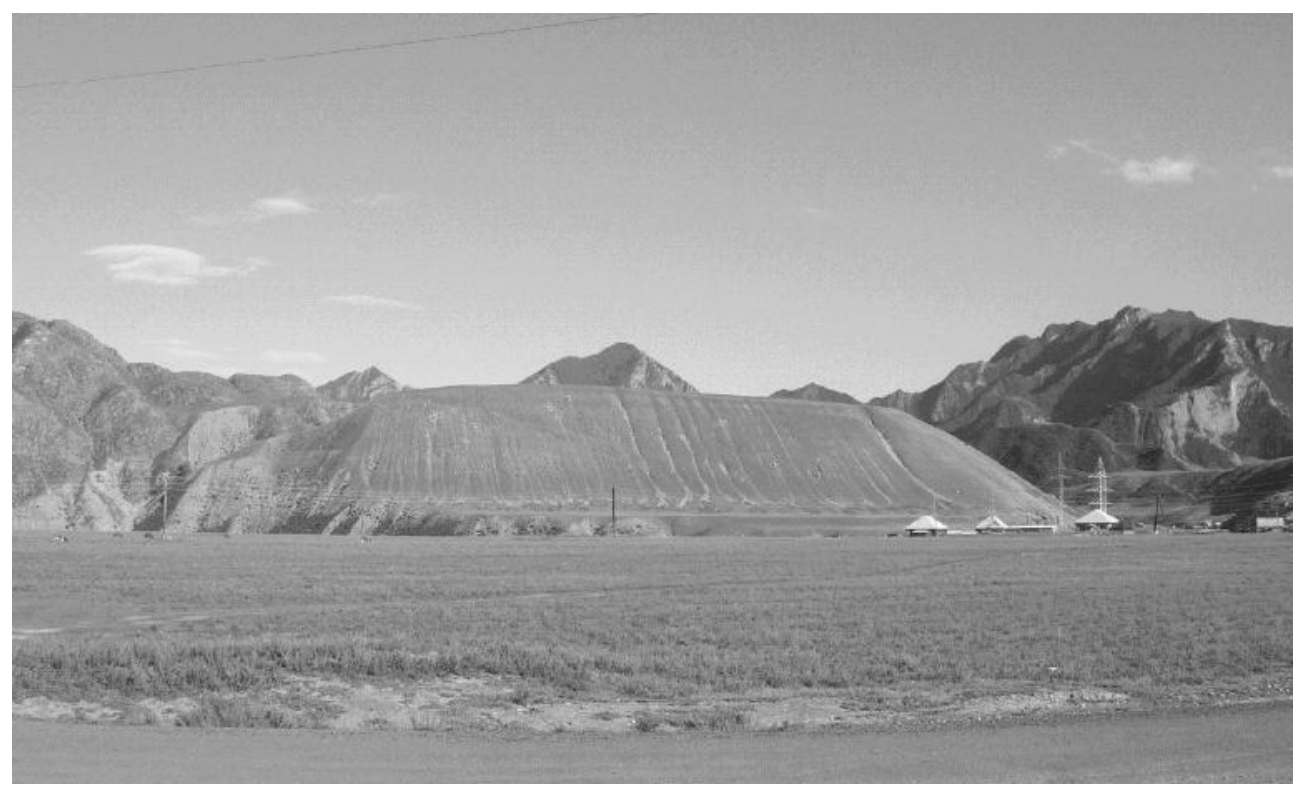

Photo 3. Megaflood terrace in the Altay. The entire terrace was formed as a result of single flood episode. Photo by JA.M.G. 
All above-mentioned megafloods were, undoubtedly, natural catastrophes. Their direct actions and consequences were restricted to particular regions even if large. On a larger scale, they were just peculiar geologic events. There is, however, an example of megaflood with global-scale consequences. This was a cataclysmic discharge of fresh water $\left(6 \times 100 \mathrm{~m}^{3} / \mathrm{s}\right)$ from the proglacial Lakes Agassiz and Ojibway to the Atlantic Ocean, which perturbed major circulation patterns, produced the short-term cooling at $\sim 8.2 \mathrm{ka}$, and induced the global sea-level change (CLARKE et al., 2004; KENDALL et al., 2008; LEGRANDE, 2009; ANDERSON \& ANDERSON, 2010). It was earlier hypothesized that outflow from the same Lake Agassiz might have been responsible for the Younger Dryas event, but this idea is now under critical examination (TELLER et al., 2005; BROECKER et al., 2010).

\section{Extraterrestrial impacts: scaling by diversity of consequences}

Extraterrestrial impacts are not uncommon in the geologic past (ABBOTT \& ISLEY, 2002; NAPIER, 2008). Some of them were extraordinary with respect to diversity of consequences. The most spectacular were those events that occurred in the very early history of the Earth. Collisions with large (with a size up to that of Mars) extraterrestrial bodies were able to melt significant portions of the crust, to remix the core and mantle, to strip the atmosphere, and to re-homogenize the entire planet; it remains under discussion how many such catastrophes occurred before $4.45 \mathrm{Ga}$ and which of them was responsible for creation of the Moon (ZHANG, 2005).

An extraterrestrial body with the size of about $10 \mathrm{~km}$ collided with the Earth at the Cretaceous/Paleogene boundary and produced global wildfires, giant tsunami waves, climate perturbations, and the wellknown mass extinction (ALVAREZ, 2008; SCHULTE et al., 2010). This scenario generated various criticisms. Some authors propose another cause (e.g., volcanism) of the environmental catastrophe (COURTILLOT, 2007), others suggest another impact event (KELLER, 2008), some provide an evidence that the hypothesized impact was not so destructive (BELCHER et al., 2004, 2005), and some still question an idea of sudden mass extinction (STOW, 2010). Anyway, the above-mentioned scenario provides an example of global-scale environmental perturbation, which altered all levels of the biosphere and atmosphere and had such exceptional outcomes like $100 \mathrm{~m}$-tsunami waves and planetary-persisting wildfires (WOLBACH et al., 1990; VAJDA et al., 2001; DYPVIK \& JANSA, 2003; ALVAREZ, 2008). Even if some dinosaurs and ammonites passed the Cretaceous/Paleogene boundary (Fassett et al., 2002; MACHALSKI \& HEINBERG, 2005; FASSETT, 2009; MACHALSKI et al., 2009; ROVELLI et al., 2010), these were "Dead Clades Walking" in terms of Jablonski (2004). In other words, this was a catastrophe with the highest possible diversity of consequences for the Earth's geologic evolution. Another extraterrestrial impact has been recently hypothesized to happen at the end-Pleistocene (FIRESTONE et al., 2007; KENNETT et al., 2009). This idea faces strong criticism (e.g., SUROVELL \& HOLLIDAY, 2009; Broecker et al., 2010; see also Appendix), but the relevant disputes are not yet ended. If this $\sim 12.9 \mathrm{ka}$ event occurred, it was a catastrophe, which provoked megafaunal extinctions and interruption of early human cultures in North America; moreover, 
this impact might have been responsible for the Younger Dryas global cooling (FIRESTONE et al., 2007; KENNETT et al., 2009). Thus, despite its lesser magnitude, the endPleistocene catastrophe (of course, if further proved) seems to be comparable by diversity of its consequences with what happened at the Cretaceous/Paleogene boundary.

The Odessa hypervelocity impact occurred in the Pleistocene on the southern High Plains of North America; it devastated local ecosystems, although this effect was limited to a radius of $2 \mathrm{~km}$ (HOLLIDAY et al., 2005). This event likely did not trigger any significant changes in climate or biosphere. The Eltanin impact took place in the South Pacific at $\sim 2.15 \mathrm{Ma}$, when a large (up to $4 \mathrm{~km}$ in size) extraterrestrial body collided with the Earth (WARD \& ASPHAUG, 2002). Although it altered the bottom sediments and produced a giant tsunami wave (FLORES et al., 2002; WARD \& ASPHAUG, 2002), this impact apparently did not affect the Earth's climate or biosphere (FLORES et al., 2002). Were these two events catastrophes with respect to diversity of their consequences? If we consider only the sequence of the Earth's collisions with other bodies, each event constituting this sequence should be judged catastrophic. In contrast, when one addresses the geologic evolution with its entire complexity, the Odessa and Eltanin impacts were close to "ordinary" events.

\section{Mass extinctions: scaling by temporal expression}

A series of mass extinctions occurred in the geologic past (RAUP \& SEPKOSKI, 1982; SEPKOSKI \& RAUP, 1986; HALLAM \& WIGNALL, 1997; HALLAM,
2005; BAMBACH, 2006; RACKI, 2009). Five of them (end-Ordovician, Frasnian/ Famennian, Permian/Triassic, end-Triassic, and Cretaceous/Paleogene) are considered major, and they are often called the Big Five. Scaling of mass extinctions by their temporal expression is difficult even if possible. Both duration and abruptness are excluded as significant parameters. On one hand, there are certain pitfalls in their evaluation (e.g., VAN LOON, 1999). On the other hand, consideration of neither duration nor abruptness facilitates a distinction of catastrophes from "ordinary" events. E.g., the end-Ordovician mass extinction linked with a glaciation (MUNNECKE et al., 2010) was apparently longer and less abrupt than the asteroid-triggered Cretaceous/Paleogene mass extinction (ALVAREZ, 2008; SCHULTE et al., 2010). However, both were recognizable biotic catastrophes.

Consideration of frequency poses a more complicated task. One may assume that higher frequency of events means they were "ordinary" in the geologic past. If so, major mass extinctions (the Big Five) were catastrophes, whereas minor mass extinctions (all others except for Big Five), significantly more frequent, were not. Alternatively, minor mass extinctions were "lesser" catastrophes. A distinction of major and minor mass extinctions, however, seems to be outdated. On one hand, it has been realized that some "minor" biotic collapses were comparable in their magnitude with those "major" (e.g., RUBAN \& TYSZKA, 2005). On the other hand, even such dramatic mass extinctions like that Permian/Triassic (ERWIN, 2006) were not so all-embacing. E.g., XIONG \& WANG (2011) reported a rather gradual floristic turnover across the Permian-Triassic transition, but not mass extinc- 
tion. When Luo et al. (2008) recognized the so-called Lilliput Effect among conodonts at a time of mass extinction, CHUNIKHIN (2008) documented an opposite pattern (i.e., increase in body size) among conchostracans. Moreover, some new significant biotic crises have been recognized. An example is the Early Silurian crisis, although its nature remains debated (RUBAN, 2008; LEHNERT et al., 2010). Consequently, all mass extinctions known from the geologic past should be considered together as events of the same sequence. This conclusion implies that the frequency of mass extinctions in the geologic past was high. There were no periods without mass extinctions, and in some periods like the Devonian or the Permian, life on the Earth experienced a series of such perturbations. Following the assumption given above, such high frequency indicates that mass extinctions were not catastrophes, which is evidently wrong. Increasing the resolution of our analysis, we can see that the Permian provides a fascinating example. The first mass extinction of this period was mid-Capitanian in age (BOND et al., 2010a,b). Further studies are necessary in order to understand whether it predated the earlier-hypothesized end-Guadalupian mass extinction (e.g., STANLEY \& YANG, 1994; HALLAM \& WIGNALL, 1997) or the latter should be re-considered as the midCapitanian (additionally, CLAPHAM et al. (2009) suggested rejecting any Permian biotic catastrophe until the Permian/Triassic). And the next mass extinction took place already at the Permian/Triassic boundary (ERWIN, 2006). Such a concentration of events within the time interval of just $\sim 10$ Ma does not disprove their catastrophic nature. The frequency of events does not matter for a distinction of catastrophes from the "ordinary" events as well as the whole temporal expression of events. Geologic history can consist of a chain of "ordinary" events, a chain of catastrophes, or a chain of "ordinary" events superimposed by catastrophes.

\section{DISCUSSION}

The examples presented above suggest that catastrophes can be distinguished from other events in the geologic past by their spatial extent and diversity of consequences. In other words, two-dimensional scaling does matter. It appears to be a sufficient supplement to the ranking of events by their magnitude. But where is the boundary between catastrophes and "ordinary events" according to the scaling? Focusing on smaller areas and only particular aspects of the geologic history increases the importance of some events and makes them catastrophes. This means the noted boundary is dynamic, depending on our needs, and, consequently, it is rather subjective.

Both Missoula (and analogous megafloods in Southern Siberia) and AgassizOjibway megafloods were catastrophes as well as the Chicxulub and Eltanin extraterrestrial impacts. But these pairs do not include catastrophes of comparable scales (Fig. 2). It appears that the geologic history of the Earth should include only global-scale and highly-comprehensive catastrophes. Regional-scale and less-comprehensive (i.e., lessdiverse) events, if even such outstanding as the Noah's Flood or the Odessa impact, were "ordinary" from the planetary point of view. This means that sequences of events should be established separately for the Earth and the particular regions as well as for the selected aspects of the planetary evolution and this evolution taken in the whole. Any mix of these sequences should be avoided. 


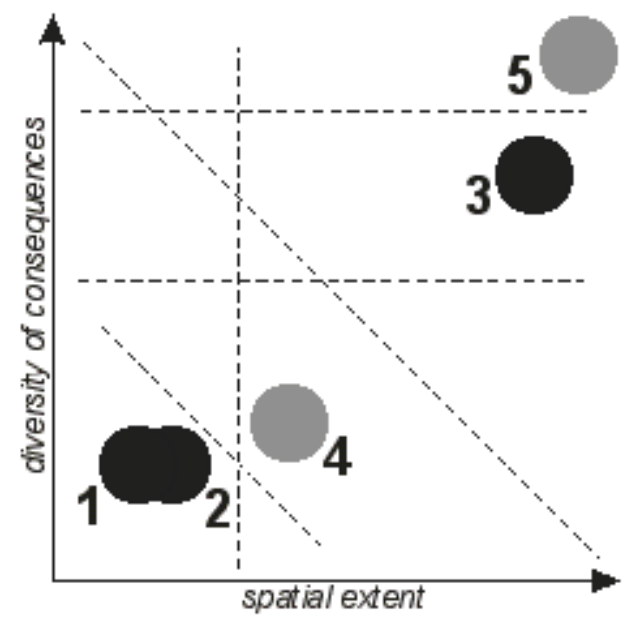

Fig. 2. Conceptual scaling of megafloods (black: 1 - Missoula, 2 - Altay, 3 - Agassiz-Ojibway) and extraterrestrial impacts (grey: 4 - Eltanin, 5 - Chicxulub). Distinction between catastrophes and "ordinary" events can be made provisionally depending of subjective needs and preferences (few possible examples of such a distinction are shown by dashed lines).

The consideration presented just above is a very important premise for broad implications of the event analysis in modern geoscience. This analysis focuses on a recognition and distinction of events and establishes their characteristics later. The event analysis is not biased by consideration of the only somewhat exceptional (RUBAN, 2006). This technique allows multi-level and dynamic distinction between catastrophes and other events, which is inevitable as suggested by examples presented in this essay. If so, modern geoscientists should not only favour event analysis, but make its clear distinction from approachs of neocatastrophism (the latter is a general term for concepts, which treat catastrophes as the main events in the geologic history or even as the driving force of the Earth's development). Similarly-sounded suggestion by BABIN (2007) is, therefore, not an appeal, but valuable instruction.

\section{CONCLUSIONS}

Examples of megafloods, extraterrestrial impacts, and mass extinctions known from geologic history demonstrate that not only magnitude, but also scale is important for a clear distinction of catastrophes from "ordinary" events. Two-dimensional scaling, which involves spatial extent and diversity of consequences, is implied in order to establish the nature of events. However, recognition of catastrophes is rather a subjective procedure, which depends heavily on our needs. The boundary between catastrophes and "ordinary" events is subjective. When the geologic past is discussed, it should be stated clearly what scale is considered. E.g., only those events, which appeared globally and altered several aspects of the Earth's evolution, should be evaluated as catastrophes in the geologic history of the entire planet. 
The present essay offers a tentative treatment of the problem of geologic event scaling. Further conceptual discussion of catastrophes is necessary. But even more important is a balanced consideration of catastrophes and "ordinary" events. Focusing on only the former is not a way to clear understanding of the geologic past.

\section{ACKNOWLEDGEMENTS}

The authors gratefully thanks J.R. VIDAL ROMANÍ (Spain) for his editorial support and P.F. KARROW (Canada) for his preliminary review of this paper. The help with literature provided by P.F. KARROW (Canada), W. RIEGRAF (Germany), A.J. VAN LOON (Netherlands/Poland), Q. WANG (China), and other colleagues is appreciated. Brief communications with E.A. MEDLEY (USA) and R. ROVELLI (USA), who both are thanked, allowed us to account for some very new results. D.A.R. acknowledges feedback from his students attending the lectures on geologic event analysis at the Southern Federal University (Russia).

\section{APPENDIX}

Two professional descriptions of the Pleistocene Lake Missoula and its catastrophic floods are available on-line at:

http://www.glaciallakemissoula.org/ http://vulcan.wr.usgs.gov/Glossary/Glaciers/IceSheets/description_lake_missoula. html

A balanced overview of debates on the hypothesis about the Younger Dryas extraterrestrial impact is available on-line at:

http://www.csicop.org/si/show/did_a_ cosmic_impact_kill_the_mammoths/

\section{REFERENCES}

ABBOTT, D. H. And ISLEY, A. E. (2002). Extraterrestrial influences on mantle plume activity. Earth and Planetary Science Letters, 205: 53-62.

AKSU, A. E., HISCOTT, R. N., MUDIE, P. J., ROCHON, A., KAMINSKI, M. A., ABRAJANO, T. and YAŞAR, D. (2002). Persistent Holocene outflow from the Black Sea to the Eastern Mediterranean contradicts Noah's Flood hypothesis. GSA Today, 12: 4-10.

ALVAREZ, W. (2008). T. rex and the Crater of Doom. Princeton University Press, Princeton, $185 \mathrm{pp}$.

ANDERSON, R. S. and ANDERSON, S.P. (2010). Geomorphology: The Mechanics and Chemistry of Landscapes. Cambridge University Press, Cambridge, 637 pp.

BABIN, C. (2007): Autour du catastrophisme: Des mythes et legendes aux sciences de la vie et de la Terre. Vuibert, ADAPT/ SNES, Paris, 170 pp.

BAMBACH, R. K. (2006). Phanerozoic biodiversity and mass extinctions. Annual Review of Earth and Planetary Sciences, 34: 127-155.

BEEKWITH, M. W. (1981). The Kumulipo: A Hawaiian Creation Chant. University of Hawaii Press, Honolulu, 257 pp.

BELCHER, C. M., Collinson, M. E. and Scott, A.C. (2004). Fireball passes and nothing burns-The role of thermal radiation in the Cretaceous-Tertiary event: Evidence from the charcoal record of North America. Geology, 31: 1061-1064.

BELCHER, C. M., Collinson, M. E. and Scott, A.C. (2005). Constraints on the thermal energy released from the Chicxulub impactor: new evidence from 
multi-method charcoal analysis. Journal of the Geological Society, London, 162: 591-602.

BENITO, G. and O'CONNOR, J.E. (2003). Number and size of last-glacial Missoula floods in the Columbia River valley between the Pasco Basin, Washington, and Portland, Oregon. Geological Society of America Bulletin, 115: 624-638.

BENNETT, M. R. and GLASSER, N. F. (2009). Glacial Geology: Ice Sheets and Landforms. Wiley-Blackwell, Chichester, $385 \mathrm{pp}$.

BERGGREN, W. A. and VAN COUVERIG, J. A., Eds. (1984). Catastrophes and Earth History. Princeton University Press, 464 pp.

BOGGS, S., Jr. (2006). Principles of Sedimentology and Stratigraphy. Pearson Prentice Hall, Upper Saddle River, 662 pp.

BOND, D. P. G., WIGNALL, P. B., WANG, W., IZON, G., JIANG, H.-S., LAI, X.-L., SUN, Y.-D., NEWTON, R. J., SHAO, L.-Y., VÉDRINE, S. and COPE, H. (2010a). The mid-Capitanian (Middle Permian) mass extinction and carbon isotope record of South China. Palaeogeography, Palaeoclimatology, Palaeoecology, 292: 282-294.

BOND, D. P. G., HILTON, J., WIGNALL, P. B., ALI, J. R., STEVENS, L. G., SUN, Y. and LAI, X. (2010b). The Middle Permian (Capitanian) mass extinction on land and in the oceans. Earth-Science Reviews, 102: 100-116.

BOSTROM, N. and ĆIRKOVIĆ, M.M. (2008). Introduction. In: Bostrom, N. \& Ćirković, M.M. (Eds.). Global Catastrophic Risks. Oxford University Press, Oxford, pp. 1-29.

BRETZ, J. H. (1969). The Lake Missoula floods and the channeled scabland.
Journal of Geology, 77: 505-543.

BROECKER, W. S., DENTON, G. H., EDWARDS, R. L., CHENG, H., ALLEY, R. B. and PUTNAM, A.E. (2010). Putting the Younger Dryas cold event into context. Quaternary Science Reviews, 29: 1078-1081.

BUTVILOVSKIJ, V. V. (1993). Paleogeografija poslednoge oledenenija i golotsena Altaja: $\quad$ sobytijno-katastrofitcheskaja model' [Palaeogeography of the Last Glacial and the Holocene of the Altay: event-catastrophic model]. Tomskij universitet, Tomsk, 253 pp. (in Russian)

CHUNIKHIN, S. A. (2008). Taksonomitcheskaja kharakteristika granitsy permi i triasa po konkhostrakam [Taxonomic characteristics of the Permian/Triassic boundary by conchostracans]. In: Papin, Yu.S. (Ed.). Bio - i litostratigrafitcheskie rubezhi $v$ istorii Zemli. TyumGNGU, Tyumen, pp. 261-265. (in Russian)

CLAGUE, J. J., BARENDREGT, R. W., ENKIN, R. J. and FOIT, N., Jr. (2003). Paleomagnetic and tephra evidence for tens of Missoula floods in southern Washington. Geology, 31: 247-250.

CLAPHAM, M. E., SHEN, S. and BOTTJER, D.J. (2009). The double mass extinction revisited: reassessing the severity, selectivity, and causes of the end-Guadalupian biotic crisis (Late Permian). Paleobiology, 35: 32-50.

CLARKE, G. K. C., LEVERINGTON, D. W., TELLER, J. T. and DYKE, A. S. (2005). Paleohydraulics of the last outburst flood from glacial Lake Agassiz and the 8200 BP cold event. Quaternary Science Reviews 23, 389-407.

COURTILLOT, V. (2007). Evolutionary Catastrophes - The Science of Mass 
Extinction. Cambridge University Press, Cambridge, 173 pp.

DURY, G. H. (1980). Neocatastrophism? A further look. Progress in Physical Geography, 4: 391-413.

DYPVIK, H. and JANSA, L.F. (2003). Sedimentary signatures and processes during marine bolide impacts: a review. Sedimentary Geology, 161: 309-337.

ERWIN, D. H. (2006). Extinction: How Life on Earth Nearly Ended 250 Million Years Ago. Princeton University Press, Princeton, 306 pp.

FASSETT, J. E. (2009). New chronologic and stratigraphic evidence confirms the Paleocene age of the dinosaur-bearing Ojo Alamo Sandstone and Animas Formation in the San Juan Basin, New Mexico and Colorado. Palaeontología Electrónica, 12 (1-3A): 1-146.

FASSETT, J. E., ZIELINSKI, R. A. and BUDAHN, J. R. (2002). Dinosaurs that did not die: Evidence for Paleocene dinosaurs in the Ojo Alamo Sandstone, San Juan Basin, New Mexico. Geological Society of America Special Paper, 356: 307-336.

FIRESTONE, R.B., WEST, A., KENNETT, J. P., BECKER, L., BUNCH, T. E., REVAY, Z. S., SCHULTZ, P. H., BELGYA, T., KENNETT, D. J., ERLANDSON, J. M., DICKENSON, O. J., GOODYEAR, A. C., HARRIS, R. S., HOWARD, G. A., KLOOSTERMAN, J. B., LECHLER, P., MAYEWSKI, P. A., MONTGOMERY, J., POREDA, R., DARRAH, T., QUE HEE, S. S., SMITH, A. R., STICH, A., TOPPING, W., WITTKE, J. H. and WOLBACH, W. S. (2007). Evidence for an extraterrestrial impact 12,900 years ago that contributed to the megafaunal extinctions and the
Younger Dryas cooling. Proceedings of the National Academy of Sciences, 104: 16016-16021.

FLORES, J.-A., SIERRO, F. J. and GERSONDE, R. (2002). Calcareous plankton stratigraphy around the Pliocene "Eltanin" asteroid impact area (SE Pacific): documentation and application for geological and paleoceanographic reconstruction. Deep Sea Research Part II: Topical Studies in Oceanography, 49: 1011-1027.

GÖRÜR, N., ÇAĞATAY, M. N., EMRE, Ö., ALPAR, B., SAKINÇ, M., ISLAMOĞLU, Y., ALGAN, O., ERKAL, T., KEÇER, M., AKKÖK, R. and KARLIK, G. (2001). Is the abrupt drowning of the Black Sea shelf at $7150 \mathrm{yr}$ BP a myth? Marine Geology, 176: 65-73.

GROSVALD, M. G. (1999). Evrazijskie gidrosfernye katastrofy $i$ oledenenie Arktiki [Eurasian hydrospheric catastrophes and the glaciation of Arctic]. Nautchnyj mir, Moskva, 128 pp. (in Russian)

GUTAK, Ja. M. (2008). Diluvial'nyj sedimentogenez $\mathrm{v}$ istorii Zemli [Dilavial sedimentation in the history of the Earth]. In: JAPASKURT, O.V. \& MASLOV, A.V. (Eds.) .Tipy sedimentogeneza $i$ litogeneza i ikh evoljutsija v istorii Zemli. Vol. 1. IGG UrO RAN, Ekaterinburg, pp. 187-189. (in Russian)

GUTAK, JA. M. and ANTONOVA, V. A. (2006a). Krasnotsvetnye otlozhenija $\mathrm{v}$ pribrezhno-morskokih fatsijakh (model' formirovanija na primere pozdnedevonskikh otlozhenij Kuzbassa) [Red-coloured deposits in the nearshore facies (formation model by example of Late Devonian deposits of the Kuzbass)]. Izvestija Bijskogo otdelenija Russkogo geografitcheskogo obtschestva, 26: 95-97. (in Russian) 
GUTAK, JA. M. and ANTONOVA, V. A. (2006b). Red-coloured adjournment in seashore facies (formation model on an example of the Upper Devonian adjournment of Kuzbass). Proceedings of the XVIIIth Congress of the CarpathianBalkan Geological Association, September 3-6, 2006, Belgrade, Serbia. Belgrade, pp. 193-196.

GUTAK, JA. M., ANTONOVA, V. A., BAGMET, G. N., GABOVA, M. F., SAVITSKIJ, V. R. and TOLOKONNIKOVA, Z. A. (2008). Otcherki po istoritcheskoj geologii Kemerovskoj oblasti [Discourses on the historical geology of the Kemerovo Region]. Izdatel'stvo KuzGPA, Novokuznetsk, 133 pp. (in Russian)

HALLAM, A. (2005). Catastrophes and Lesser Calamities - The Causes of Mass Extinctions. Oxford University Press, Oxford. 240 pp.

HALLAM, A. and WIGNALL, P.B. (1997). Mass Extinctions and their Aftermath. Oxford University Press, Oxford, 320 pp.

HICKEY, L. J. (1992). Dragged toward Armageddon: A Changing Paleontological Viewpoint on Catastrophism. AAPG Anuual Convention. Abstracts. Calgary, pp. 5556.

HOLLIDAY, V. T., KRING, D. A., MAYER, J. H. and GOBLE, R.J. (2005). Age and effects of the Odessa meteorite impact, western Texas, USA. Geology, 33: 945-948.

HOUGHTON, J. (2009). Global Warming. The Complete Briefing. Cambridge University Press, Cambridge, 438 pp.

JABLONSKI, D. (2004). The evolutionary role of mass extinctions: disaster, recovery and something in-between. In: TAYLOR, P.D. (Ed.). Extinctions in the history of life. Cambridge University Press, Cambridge, pp. 151-177.
KARROW， P. F. (1989). Quaternary continental stratigraphy and eocatastrophism. Quaternary Science Reviews, 8: 277-282.

KELLER, G. (2008). Cretaceous climate, volcanism, impacts, and biotic effects. Cretaceous Research, 29: 754-771.

KENDALL, R. A., MITROVICA, J. X., MILNE, G. A., TORNQVIST, T. E. and LI, Y. (2008). The sea-level fingerprint of the $8.2 \mathrm{ka}$ climate event. Geology, 36: 423-442.

KENNETT, D. J., KENNETT, J. P., WEST, G. J., ERLANDSON, J. M., JOHNSON, J. R., HENDY, I. L., WEST, A., CULLETON, B. J., JONES, T. L. and STAFFORD, T. W., JR. (2009). Wildfire and abrupt ecosystem disruption on California's Northern Channel Islands at the Allerød-Younger Dryas boundary (13.0-12.9 ka). Quaternary Science Reviews, 27: 2530-2545.

LEGRANDE, A. (2009). The 8,200Year BP Event. In: GORNITZ, V., Ed. Encyclopedia of Paleoclimatology and Ancient Environments. Springer, Dordrecht, pp. 938-943.

LEHNERT, O., MÄNNIK, P., JOACHIMSKI, M. J., CALNER, M. and FRÝDA, J. (2010). Palaeoclimate perturbations before the Sheinwoodian glaciation: A trigger for extinctions during the 'Ireviken Event'. Palaeogeography, Palaeoclimatology, Palaeoecology, 296: 320-331.

LERICOLAIS, G., BULOIS, C., GILLET, H. and GUICHARD, F. (2009). High frequency sea level fluctuations recorded in the Black Sea since the LGM. Global and Planetary Change, 66: 65-75.

LUO, G., LAI, X., SHI, G. R., JIANG, H., YIN, H., XIE, S., TONG, J., ZHANG, K., HE, W. and WIGNALL, P.B. (2008). Size variation of conodont elements of the Hindeodus-Isarcicella clade 
during the Permian-Triassic transition in South China and its implication for mass extinction. Palaeogeography, Palaeoclimatology, Palaeoecology, 264: 176-187.

MACHALSKI, M. and HEINBERG, C. (2005). Evidence for ammonite survival into the Danian (Paleogene) from the Cerithium Limestone at Stevns Klint, Denmark. Bulletin of the Geological Society of Denmark, 52: 97-111.

MACHALSKI, M., JAGT, J. W. M., HEINBERG, C., LANDMAN, N. H. and HÅKANSSON, E. (2009). Dańskie amonity - obecny stan wiedzy i perspektywy badań. Przeglad Geologiczny, 57: 486-493.

MARRINER, N., MORHANGE, C. and SKRIMSHIRE, S. (2010). Geoscience meets the four horsemen?: Tracking the rise of neocatastrophism. Global and Planetary Change, 74: 43-48.

MEDLEY, E. A. and BURNS, S. F. (2010). Ancient cataclysmic floods in the Pacific Northwest; ancestors to the Missoula Floods. Geological Society of America Abstracts with Programs, 42 (5), 310.

MILNE, A. (2000). Doomsday: The Science of Catastrophic Events. Praeger, Westport, 208 pp.

MUNNECKE, A., CALNER, M., HARPER, D. A. T. and SERVAIS, T. (2010). Ordovician and Silurian sea-water chemistry, sea level, and climate: A synopsis. Palaeogeography, Palaeoclimatology, Palaeoecology, 296: 389-413.

NAPIER, W. (2008). Hazards from comets and asteroids. In: BOSTROM, N. \& ĆIRKOVIĆ, M.M. (Eds.). Global Catastrophic Risks. Oxford University Press, Oxford, pp. 222-237.

O'CONNOR, J. E. and BAKER, V. R. (1992). Magnitudes and implications of peak discharges from glacial Lake
Missoula. Geological Society of America Bulletin, 104: 267-279.

OGG, J. G., OGG, G. and GRADSTEIN, F. M. (2008). The Concise Geologic Time scale. Cambridge University Press, Cambridge, 177 pp.

PLUHAR, C. J., BJORNSTAD, B. C., REIDEL, S. P., COE, S. R. and NELSON, P. B. (2006). Magnetostratigraphic evidence from the Cold Creek bar for onset of ice-age cataclysmic floods in eastern Washington during the early Pleistocene. Quaternary Research, 65: 123-135.

POSNER, R. (2004). Catastrophe: Risk and Response. Oxford University Press, Oxford, $322 \mathrm{pp}$.

RACKI, G. (2009). Wielkie wymimierania i ich przyczyny. Kosmos, 58: 529-545.

RAUP, D. W. and SEPKOSKI, J. J., JR. (1982). Mass extinctions in the marine fossil record. Science, 215: 1501-1503.

REY, J. and GALEOTTI, S., Eds. (2008). Stratigraphy terminology and practice. TECHNIP, Paris, 166 pp.

ROVELLI, R., GARB, M.P. and LANDMAN, N.H. (2010). Death and recovery at the K/T boundary: evidence from new sites in New Jersey. Geological Society of America Abstracts with Programs, 42 (5), 255.

RUBAN, D. A. (2006). Sobytijnyj analiz v naukakh o Zemle [Event analysis in the Earth Sciences]. UPL RGU, Rostov-naDonu, 18 pp. (in Russian)

RUBAN, D. A. (2008). Silurian biotic crises in the northern Greater Caucasus (Russia): a comparison with the global record. Paleontological Research, 12: 387-395.

RUBAN, D. A. and TYSZKA, J. (2005). Diversity dynamics and mass extinctions of the Early-Middle Jurassic foraminifers: A record from the Northwestern Caucasus. 
Palaeogeography, Palaeoclimatology, Palaeoecology, 222: 329-343.

RUDOY, A. N. (2002). Glacier-dammed lakes and geological work of glacial superfloods in the Late Pleistocene, Southern Siberia, Altai Mountains. Quaternary International, 87: 119-140.

RYAN, W. and PITMAN, W. C., III (1999). Noah's Flood: The New Scientific Discoveries about the Event that Changed History. Simon and Schuster, New York, 319 pp.

RYAN, W. B. F., MAJOR, O. C., LERICOLAIS, G. and GOLDSTEIN, S. L. (2003). Catastrophic flooding of the Black Sea. Annual Review of Earth and Planetary Sciences, 31: 525-554.

SCHÖNLAUB, H.-P. (1996). Scenarios of Proterozoic and Paleozoic catastrophes: A review. Abhandlungen der Geologischen Bundesanstalt, 53: 59-75.

SCHULTE, P., ALEGRET, L., ARENILLAS, I., ARZ, J. A., BARTON, P. J., BOWN, P. R., BRALOWER, T. J., CHRISTESON, G. L., CLAEYS, P., COCKELL, C. S., COLLINS, G. S., DEUTSCH, A., GOLDIN, T. J., GOTO, K., GRAJALES-NISHIMURA, J. M., GRIEVE, R. A. F., GULICK, S. P. S., JOHNSON, K. R., KIESSLING, W., KOEBERL, C., KRING, D. A., MACLEOD, K. G., MATSUI, T., MELOSH, J., MONTANARI, A., MORGAN, J. V., NEAL, C. R., NICHOLS, D. J., NORRIS, R. D., PIERAZZO, E., RAVIZZA, G., REBOLLEDO-VIEYRA, M., REIMOLD, W. U., ROBIN, E., SALGE, T., SPEIJER, R. P., SWEET, A. R., URRUTIA-FUCUGAUCHI, J., VAJDA, V., WHALEN, M. T. and WILLUMSEN, P.S. (2010). The Chicxulub Asteroid Impact and Mass Extinction at the Cretaceous-Paleogene Boundary. Science, 327: 1214-1218.
SEPKOSKI, J. J., JR. and RAUP, D. (1986). Periodicity in mass extinction events. In: ELliOTT, D. K. (Ed.). Dynamics of Extinction. Wiley, New York, pp. 3-36.

STANLEY, S. M. and YANG, X. N. (1994). A double mass extinction at the end of the Paleozoic Era. Science, 266: 1340 1344.

STOW, D. (2010). Vanished Ocean: How Tethys Reshaped the World. Oxford University Press, Oxford, 300 pp.

SUROVELL, T. A. and HOLLIDAY, V. T. (2009). Non-reproducibility of Younger Dryas extraterrestrial impact results. Geological Society of America Abstracts with Programs, 41( 7): p. 595

TELLER, J. T., BOYD, M., YANG, Z., KOR, P. S. G. and FARD, A. M. (2005). Alternative routing of Lake Agassiz overflow during the Younger Dryas: new dates, paleotopography, and a reevaluation. Quaternary Science Reviews, 24: 1890-1905.

VAJDA, V., RAINE, J. I. and HOLLIS, C. J. (2001). Indication of Global Deforestation at the Cretaceous-Tertiary Boundary by New Zealand Fern Spike. Science, 294: 1700-1702.

VAN LOON, A. J. (1999). The meaning of 'abruptness' in the geological past. Earth-Science Reviews, 45: 209-214.

VAN LOON, A. J. (2009). Reflections on subglacial megafloods: their possible cause, occurrence, and consequence for the global climate. Geologos, 15, 115128.

WARD, S. N. and ASPHAUG, E. (2002). Impact tsunami-Eltanin. Deep Sea Research Part II: Topical Studies in Oceanography, 49: 1073-1079.

WOLBACH, W. S., GILMOUR, I. and ANDERS, E. (1990). Major wildfires at the Cretaceous/Tertiary boundary. In: SHARPTON, V.L. \& WARD, P.D. (Eds.). Global Catastrophes in Earth 
History; An Interdisciplinary Conference on Impacts, Volcanism, and Mass Mortality. Geological Society of America Special Paper, 247: 391-400.

XIONG, C. and WANG, Y. (2011). Permian-Triassic land-plant diversity in South China: Was there a mass extinction at the Permian/Triassic boundary? Paleobiology, 37: 157-167.
YANKO-HOMBACH, V., GILBERT, A. S., PANIN, N. and DOLUKHANOV, P. M., Eds. (2007). The Black Sea Flood Question: Changes in Coastline, Climate, and Human Settlement. Springer, Dordrecht, $971 \mathrm{pp}$.

ZHANG, Y. (2005). The age and accretion of the Earth. Earth-Science Reviews, 59, 235-263. 